Border Renaissance 
History, Culture, and Society Series

Center for Mexican American Studies (CMAS)

University of Texas at Austin 


\section{Border Renaissance}

The Texas Centennial and the Emergence of Mexican American Literature

JOHN MORÁN GONZÁLEZ

University of Texas Press $\mathbf{v}$ Austin 
Copyright $\odot 2009$ by the University of Texas Press

All rights reserved

Printed in the United States of America

First edition, 2009

Requests for permission to reproduce material from this work should be sent to:

Permissions

University of Texas Press

P.O. Box 7819

Austin, TX 78713-7819

www.utexas.edu/utpress/about/bpermission.html

@ The paper used in this book meets the minimum requirements of ANSI/NISO Z39.48-1992 (R1997) (Permanence of Paper).

\section{Library of Congress Cataloging-in-Publication Data}

González, John Morán.

Border renaissance : the Texas centennial and the emergence of Mexican American literature / John Morán González. - 1st ed.

p. cm. - (CMAS history, culture, \& society series)

Includes bibliographical references and index.

ISBN 978-0-292-71978-1 (cloth : alk. paper)

1. American literature-Mexican American authors-History and

criticism. 2. Mexican Americans in literature. 3. Race in literature. 4. Texas-In literature. 5. Mexican Americans-Intellectual life-20th century. 6. Literature and history-Texas. 7. Texas-Centennial celebrations, etc. I. Title.

PS153.M4G59 2009

$810.9^{\prime} 86872-\mathrm{dc} 22$

2009006973 
I dedicate this book, and all my tomorrows, to Patricia Garcia, amor mia, and m'ija Angelita Annette, the loves of my life. 
THIS PAGE INTENTIONALLY LEFT BLANK 